\title{
Correction to: The Anti-Jewish Narrative
}

\author{
Nathan Cofnas ${ }^{1}$
}

Published online: 27 February 2021

(c) The Author(s) 2021

\section{Correction to: Philosophia https://doi.org/10.1007/s11406-021-00322-w}

The original version of this article unfortunately contains a mistake introduced during the production phase. The author's correction to remove the last 4 sentences in the 4th paragraph of Section 3 was not carried-out.

The original article has been corrected.

Open Access This article is licensed under a Creative Commons Attribution 4.0 International License, which permits use, sharing, adaptation, distribution and reproduction in any medium or format, as long as you give appropriate credit to the original author(s) and the source, provide a link to the Creative Commons licence, and indicate if changes were made. The images or other third party material in this article are included in the article's Creative Commons licence, unless indicated otherwise in a credit line to the material. If material is not included in the article's Creative Commons licence and your intended use is not permitted by statutory regulation or exceeds the permitted use, you will need to obtain permission directly from the copyright holder. To view a copy of this licence, visit http://creativecommons.org/ licenses/by/4.0/.

Publisher's Note Springer Nature remains neutral with regard to jurisdictional claims in published maps and institutional affiliations.

The original article can be found online at https://doi.org/10.1007/s11406-021-00322-w

Nathan Cofnas

nathan.cofnas@balliol.ox.ac.uk

1 Balliol College, University of Oxford, Oxford OX1 3BJ, UK 